\section{俩 Heighten Science P U B L I C A T I O N S Corporation ISSN 2574-0350}

\title{
Natural and effective ways of purifying lake water
}

\author{
Swapnil Lokhande ${ }^{1}$ and Savita Dixit ${ }^{2 *}$ \\ ${ }^{1}$ Master of Technology, Computer Science \& Engineering, International Institute of Information \\ Technology, Bhubaneswar, India \\ ${ }^{2}$ Professor of Chemistry Department National Institute of Technology, Bhopal, India
}

\begin{abstract}
*Address for Correspondence: Dr. Savita Dixit, Professor of Chemistry Department National Institute of Technology, Bhopal, India, Email: savitadixit1@yahoo.com

Submitted: 07 June2017

Approved: 27 June 2017

Published: 29 June 2017

Copyright: @ 2017 Lokhande S, et al. This is an open access article distributed under the Creative Commons Attribution License, which permits unrestricted use, distribution, and reproduction in any medium, provided the original work is properly cited.
\end{abstract}

Keywords: Aeration unit; Macrophytes; Physicochemical; Chlorination; Water pollution

\section{ABSTRACT}

Water resources play an integral part in the life of a living being. The various water resources that are present on the earth's surface are in the form of oceans, seas, lakes, rivers, ponds, waterfalls etc. Among these water resources Lakes and reservoirs are vital for people's life, industrial activities and many other day to day activities. These water resources help in obtaining water for drinking after being treated. They also provide water for agriculture and industrial usage, fishery resource, flood control functions and many other activities. Due to the closed nature of lakes', the waste material from sewage, agricultural effluents, domestic and industrial fields, gets accumulated around the surface of these water resources and once the water gets polluted, it gets strenuous to improve the quality of the water. In the study, the authors have examined different effective ways by which the quality of lake water can be improved.

\section{INTRODUCTION}

Lakes and reservoirs are essential for people's lives, industrial activities and many other day to day activities. The water provide various benefits, such as obtaining drinking water, agriculture and industrial use and have usage in many other ways.

But the water is becoming polluted due to sewage, agricultural, domestic and industrial waste. In addition, the condition of the water is so bad that even the exceptional improving tendency of the water quality of lakes is not visible due to the increase in pollutant load in these water resources because of the increase in industrialization and population. The climatic changes also play a harmful role in decaying the quality of water. The increasing pollution in water is adversely affecting the aquatic life. However, the maintenance of a healthy aquatic ecosystem is dependent on the physico-chemical properties of water and the biological diversity [1].

Other than the industrial waste, solid waste is being deposited by the visitors each day, the Lake receives more than 140 tonnes of solid waste directly or indirectly. With the colossal amount of waste being pumped into the Lake, no sooner the waters will lose potability. This could be a serious setback to water availability in Bhopal water [2].

The water resources being selected for this study is Upper Lake and Shahpura Lake of Bhopal, the capital of Madhya Pradesh, India. Bhopal is popularly known as the city of lakes [3]. The city has more than eighteen natural water resources. Out of these, few are the sources of drinking water after preliminary treatment. Rest of the water resources are used for other purposes like irrigation, fisheries, recreational activities etc. Both these lakes are eutrophic and sewage fed lake. Several investigations and research studies have been made on water quality and increasing pollution level of 
the water body. Strangely, the studies indicate the alarming contamination of the lake which is very high as compared to the standard guidelines, revealing that nutrient load in the lake is very high and hypereutrophic conditions are prevailing. Hence, periodic monitoring and preventive measures are required to save the lake from eutrophication [4].

Due to the industrialization and urbanization of the Bhopal city, these lakes are severely affected by the heavy metals that are discharged in the environment. These heavy metals contribute to the environmental pollution as they cannot be destroyed through biological degradation. Thus, the discharge of heavy metals in this water has an adverse effect on the aquatic systems [5].

A study had been conducted to determine popular heavy metals such $\mathrm{Cu}, \mathrm{Fe}$, $\mathrm{Mn}, \mathrm{Zn}, \mathrm{Ni}, \mathrm{Cr}$ and $\mathrm{Pb}$ in the groundwater of different sites of Shahpura Lake. It has been observed that all activities associated with urban, industrial or agricultural development have direct or indirect impact on the groundwater. Undoubtedly, large scale concentrated source of pollutants such as industrial discharge and subsurface injection of chemicals for agricultural purposes are obvious sources of ground water pollutants. Indiscriminate and wasteful water consumption and improper waste disposal practices have led to deterioration in the water quality [6].

The study being conducted is based on the cost-effective and eco-friendly methods for the treatment of contaminated lake water rather than the chemical treatments. It's being observed that the use of the chemical treatments can have adverse effect on the aquatic life as well as the human beings which consume the water after being treated. Chlorination is one the water purification method. Though the method is useful in killing the bacteria present in the water, but excess chlorine in water is harmful as it amalgamates with organic material in the water to form substances such as trihalomethanes, which may cause health problems related to liver, kidney, or central nervous system, and the possibility of cancer also increases with the consumption of such water.

The study is an attempt to analyze the quality of water of both the lakes and observes the change in lake water chemistry by natural and cost effective methods. Following are the two methods:

(a) Macrophytes

(b) Aeration units

\section{METHODOLOGIES}

\section{Macrophytic technique}

A Macrophyte is an aquatic plant that grows in or near water and is emergent, submergent, or floating, and includes helophytes. In lakes and rivers macrophytes provide cover for fish, produce oxygen, and act as food for some fish and aquatic wildlife [7]. Macrophytes play a vital role in maintaining the Lake Ecosystem. The root system of these aquatic plants is so effective that it has the capacity to refine the quality of water by absorbing nutrients with their effective root system [8].

Ruppia [9], a macrophyte, also known as the widgeonweeds, ditch grasses or widgeon grass. These aquatic plants are widespread and are present in many parts of the world. They are most commonly present outside of frigid zones and the tropics.

Eichhornia crassipes (Water Hyacinth) is also one of the species of macrophytes. The roots of these macrophytes act like a source of nourishment for other aquatic microorganisms, which then provide a significant degree of treatment for their metabolism [10].With the help of the recent research activities, it's been reported that the dry material of Eichhornia crassipes is also helpful in adsorbing heavy metals which are present in the water. 


\section{Aeration}

The aerators were initially installed for beautifying the lake but latter it was observed that it can be helpful in purifying the lake water as it improves the level of dissolved oxygen in the water and also facilitate the microbial activities.

The aeration process is significantly used to remove vaporous substances and gases present in water and it improves the content of dissolved oxygen (DO) in water [11]. Aeration is the most important and essential operation unit in water treatment [12]. Aeration through aerators needs no chemicals for purification and contribute to the improvement of water quality in an eco-friendly way. It is observed that this process is more effective in warm climate [13].

\section{Methods of aeration}

Two general methods are being used for the aeration of water.

Following are the methods:

a) Water-fall aerator

b) Air diffusion aerator

\section{a) Water-Fall aerators}

Different variations of the water-fall principle are used in this type of aeration. The simplest installation of water-fall aerator employs a vertical riser that releases water by free fall into the water. The riser of the aerator unit usually operates on the available head of water. The efficiency of aeration unit can be improved significantly by increasing the fall distance.

\section{b) Air diffusion aerators}

Air diffusion aerator systems aerate by blowing air into water through perforated pipes, strainers, porous plates, or tubes. Aeration by diffusion is conceptually better than water-fall aeration method because small bubbles of air rising through water are constantly coming in contact to fresh liquid surfaces, covering large water surface per unit volume of air. Also, the velocity of bubbles rising through the water is much lower than the velocity of free-falling drops of water through water-fall aerator unit, thus providing a longer contact time. High efficiency is achieved when water flow is countercurrent to the rising air bubbles.Use of aerators is often safe and sound form of pollution removal from water. It is one of the most effective methods for restoration of urban lakes.

\section{STUDY AREA}

\section{Lower lake}

Lower Lake is situated in a thickly populated area of the old city of Bhopal. It is built in the year 1794 and has a catchment area of $9.6 \mathrm{sq}$. km. The lake receives sewage and runoff from the catchment area through number of inlets.

\section{Shahpura lake}

Shahpura Lake is another lake in the city. It is totally sewage fed and a highly eutrophic lake. The lake has a catchment area of $8.29 \mathrm{sq} . \mathrm{km}$. and a submergence area of $0.96 \mathrm{sq} . \mathrm{km}$. The lake is surrounded by residential areas from southern side, western side and eastern side. Ekant Park is in northern side of the lake. The lake receives residential waste from Panchsheel Nagar which is one of the major inlets passing through Ekant Park. The lake is primarily used for fisheries and recreational activities. 
The water quality of these lakes is becoming worse day by day due to unchecked and untreated sewage inflow, sanitation, cattle population, weeds encroachment, deforestation etc. The condition of these lakes is deteriorating and it is the right time to take certain measures for the conservation and management of the lake.

\section{MATERIALS AND METHODS}

The water samples were collected by standard methods of sample collection as prescribed in APHA [14] for both the lakes.

pH: The $\mathrm{pH}$ of water was determined using digital $\mathrm{pH}$ meter [14]. The $\mathrm{pH}$ indicates the acidity or alkalinity of water. $\mathrm{pH}$ is an important parameter because it controls the state of various nutrients including nitrate, phosphate, dissolved oxygen etc [15].

D0: The sample of water was collected for experimentation. Dissolved Oxygen was fixed instantly on the spot and the sample was analyzed immediately as per the Wrinkler's method with Azide modification [14]. The dissolved oxygen has a significant importance in an aquatic eco-system and it is also considered as an important pollution indicator parameter. It determines the biological changes which are taking place due to aerobic and anaerobic organisms. It is observed that the bottom oxygen demand is low as compared to surface water.

BOD $_{5}$ : The sample of water was collected and incubated at 200C for 5 days. The $\mathrm{BOD}_{5}$ [14] APHA is that fraction of dissolved organic matter, which is degenerate and easily absorbed by bacterial population. It is the amount of dissolved oxygen required in $\mathrm{mg} / \mathrm{l}$ for stabilizing the biodegradable organic matter by microorganisms of the sample under aerobic conditions in a stated time. It is a good index of the organic pollution and helps in deciding suitability of water for human consumption.

COD: COD was determined by potassium dichromate open reflex method [16].

Heavy metal: It determined by Atomic Absorption Spectrophotometer [14].

Nitrate and phosphate content was determined as per standard method [14]. Nitrate is one of the important parameter of pollution indicator. It is considered as an important plant nutrient.

\section{CONCLUSION \& FUTURE WORK}

The study being conducted revealed that, the aeration units significantly contributed in refining the quality of water in an eco-friendly way. With the help of Aeration units, there is a significant rise in the level of DO, which leads to the reduction of BOD and COD levels. Therefore, the study indicates that the aeration units are remarkably effective in improving water quality as well as beautifying of the lake and directly promotes tourist activity in and around Lower Lake.

Ruppia and Eichhornea Crassipes are efficient in reducing BOD, COD, TSS, Nitrate, and Phosphate. It reduces quantities of suspended particles, algae, dissolved impurities, nitrogen, phosphorus and other nutrients, turbidity, organic carbon etc. The technology is cost effective, maintenance free, self-sustained and eco-friendly. Compared with the other water treatment, natural purification methods are cost effective and sustainable than the chemical methods.

Following were the suggestions given for improving the water quality [17]:

- The Aeration units must be installed in such a way keeping in mind the effective area to be covered.

- Strict rules and regulations must be followed while setting up an industrial or residential area near the water resources. 
- Industrial and other waste material should not be dumped into the lake and proper arrangements must be made for disposing solid waste while promoting tourist activities.

The above suggestions were implemented and it's been noticed that the quality of the water of Lower Lake as well as Shahapura Lake is remarkably improved. The dumping of the waste material has also been controlled to great extent which helped in keeping the water free from pollutants. Strict guidelines to keep the water clean have been issued for the industries as well as the residential area which are in proximity of these water resources. The entire catchment area of Shahapura Lake has been fenced so that tourists do not throw any garbage material in the lake. This method has also helped to keep the water clean.

By following these methods, it has been observed that, the level of $\mathrm{pH}, \mathrm{DO}, \mathrm{BOD}_{5}$ and COD are in permissible limits. Looking at the cleanliness and the measures adopted by the agricultural department to maintain the city clean and green, the Government of India issued a list of clean and green cities in which Bhopal is ranked $2^{\text {nd }}$.

In future the aeration units can be manufactured and installed in such a way that they can be controlled electronically with the help of mobile apps so that the height and area covered by the fall of the water-fall aeration units can be changed. As it has been observed that the efficiency of aeration can be improved by increasing the fall distance. Different blocks wetlands of floating macrophytes can also be used rather than the submergent macrophytes, as these blocks can cover a larger area of the water resource and can be helpful in absorbing large amount of heavy metals and can improve the level of dissolved oxygen to a great extent.

\section{REFERENCE}

1. Agarwal AK, Rajwar GS. Physico-chemical and microbiological study of Tehri dam reservoir, Garhwal Himalaya, India. J American sci. 2010; 6: 65-71. Ref.: https://goo.gl/mrmNJm

2. Bhattacharya A, Shandilya A. Lake Water Pollution and Treatment. Int J Emerg Tech. 2017; 8: 49-52. Ref.: https://goo.gl/jKkAqy

3. Educational Britannica Educational. The geography of India: sacred and historic places. The Rosen Publishing Group. 174. Ref.: https://goo.gl/FvZ8H4

4. Sonal T, Kataria HC. Physico-Chemical studies of water quality of Shahpura lake, bhopal ( $\mathrm{mp}$ ) with special reference to pollution effects on ground water of its fringe areas. Current World Environment. 2012; 7: 139-44. Ref.: https://goo.gl/t3GJPm

5. Moore JW, Ramamoorthy S. Heavy metals in natural waters: applied monitoring and impact assessment. Springer Science \& Business Media. 2012. Ref.: https://goo.gl/WivnFj

6. Jain N. Investigation of heavy metal toxicity in ground water at Shahpura area at Bhopal. South Asia Journal of Multidisciplinary Studies. 2016; 2. Ref.: https://goo.gl/wSukMk

7. Hickey $M$, King $C$. The Cambridge illustrated glossary of botanical terms. Cambridge University Press. 2000. Ref.: https://goo.gl/2ndA4G

8. Dhote S, Dixit S. Water quality improvement through macrophytes: a case study. Asian J Exp. Sci. 2007. 21: 427-30. Ref.: https://goo.gl/7AKTid

9. Clarke SJ, Reynolds CS, Codling ID. Review of Eutrophication-related R \& D. Environment Agency. 2001. Ref.: https://goo.gl/sZYpqt

10. Crites RW. Design Manual: Constructed wetlands and aquatic plant systems for municipal wastewater treatment. US environmental protection agency, office of research and development. Center for Environmental Research Information. 1988. Ref.: https://goo.gl/nP7Qhu

11. Rao AR, Kumar $B$. The use of circular surface aerators in wastewater treatment tanks. Journal of Chemical Technology and Biotechnology. 2007; 82: 101-107. Ref.: https://goo.gl/r4u2BD

12. Chen JH, Hsu YC, Chen YF, Lin CC. Application of gas-inducing reactor to obtain high oxygen dissolution in aeration process. Water research. 2003; 37: 2919-2928. Ref.: https://goo.gl/F6P2tM 
13. Dixit S, Verma N, Tiwari S. The effects of aeration units on water quality in Upper Lake, Bhopal, India. Electronic green journal. 2005. Ref.: https://goo.gl/Xu5Cga

14. Apha A. Standard methods for the examination of water and wastewater. 1998; 20. Ref.: https://goo.gl/s4ACBa

15. Goldman C, Horne A. Limnology, Mc Graw-Hill Book co. London. 1983: 464.

16. Guidance Manual for Drinking water Quality Monitoring and assessment. NEERI. 2007. Ref.: https://goo.gl/1bnqWn

17. Dixit S, Dixit S. Cost-Effective and Eco-Friendly Methods for Lake Water-Purification. Hydro Nepal: Journal of Water, Energy and Environment. 2015; 16: 40-43. Ref.: https://goo.gl/1tGkjg 